\title{
Short-term seismic crustal deformation of Iran
}

\author{
Shoja Ansari ${ }^{\star}$, Ahmad Zamani
}

Shiraz University, Department of Earth Sciences, Shiraz, Iran

\section{Article history}

Received September 30, 2013; accepted November 26, 2013.

Subject classification:

Short-term deformation, Moment tensor, Velocity tensor, Earthquake, Iran.

\section{ABSTRACT}

In this paper the short-term seismic deformation of Iran is determined by the earthquake moment tensor summation. The study areas include the Alborz, Kopeh-Dagh, eastern Iran, Makran and Zagros orogenic belts. The spatial distribution and focal mechanisms of the earthquakes delineate the deformation zones. The mean directions of the $P$ and $T$ axes are determined by the equal area projection of the seismic moment tensors. The orientations of the P-axes are dominantly correlated with the NE crustal motion of Iran relative to Eurasia. The average strain rates are calculated in all of the regions. The maximum shear strain and dilatation rates are defined by the eigenvalues of the average strain rate tensors. The dilatation rate indicates that not only the dominant compression but also the subsidiary tension affects the Alborz and Makran orogenic belts. The velocity tensor components discriminate the vertical thickening and thinning of the crust in some regions of Iran. The seismic deformation rates, which are determined by the velocity tensors, are smaller than the geodetic deformation rates. In the high seismic deformation zones, such as the eastern Iran and Alborz, the geodetic deformation rate is comparable with the seismic deformation rate. Our results indicate that the NW Zagros and Kopeh-Dagh have the lowest seismic deformation rates. The seismic shortening rate increases from NW to SE in the Zagros orogenic belt. The seismic deformation orientations are different from the P-axes, probably due to the lateral translation. The maximum percentage of the seismic deformation in the study areas is related to the eastern Iran and the minimum one is related to the Makran orgenic belt. The average shape tensors indicate that the focal mechanisms in the Kopeh-Dagh have the highest internal similarity. The eastern Iran has the largest seismic moment rate, while the central Zagros has the lowest one.

\section{Introduction}

The Arabian-Eurasian convergent plate boundary zone is one of the largest deformation zones on the Earth [Allen et al. 2004]. The Iranian Plateau is located between the Arabian and Eurasian plates [Sobouti and Arkani-Hamed 1996] and Iran occupies the western part of the Iranian Plateau [Zamani and Hashemi 2000]. Figure 1 shows the location of Iran in the Iranian Plateau on the shaded relief map.
Deformation in the Iranian lithosphere is governed by the northern convergence of the Arabian plate relative to the Eurasian plate, lateral heterogeneities in the strength of the lithosphere [Sobouti and Arkani-Hamed 1996] and the disposition of the rigid blocks within the collision zone [Vernant and Chéry 2006]. Deformation everywhere in Iran involves intra-continental shortening except the Gulf of Oman, where oceanic lithosphere subducts northward under the SE of Iran [Byrne et al. 1992, Jackson et al. 1995].

The rates of deformation in the Arabia-Eurasia collision zone are becoming better constrained through a combination of plate circuit and Global Positioning System (GPS) studies [Allen et al. 2004]. The result of GPS networks within Iran gives lower estimates of the Arabia-Eurasia convergence rate than earlier, the nonGPS models [DeMets et al. 1990, 1994, McClusky et al. 2000, Vernant et al. 2004, Allen et al. 2006]. The primary link of GPS to the earthquake rate estimation, stems from the fact that crustal strain measured at the Earth's surface eventually manifests itself to some extent in brittle failure; that is, an earthquake [Ward 1998a].

Geodetic strain and seismic deformation (which is obtained by the seismic moment tensors) recorded over a few years, are the short-term geophysical measurements that allow one to define the strain rate tensors and their comparison is important for understanding the seismic hazard assessment [Masson et al. 2005]. The theoretical range of the seismic/geodetic strain rate ratio is between 0 and 1 if the geodetic strain rate is not biased by co- and post-seismic deformation. Larger value shows that the deformation occurs mainly seismically, in turn if it is lower, the aseismic deformation is a dominant or stress accumulation is underway which can increase the level of the seismic hazard. The seismic/geodetic ratio is consistent with the distribution of the size of the earthquakes in Iran. In the seismogenic regions where big earthquakes occur its value is 


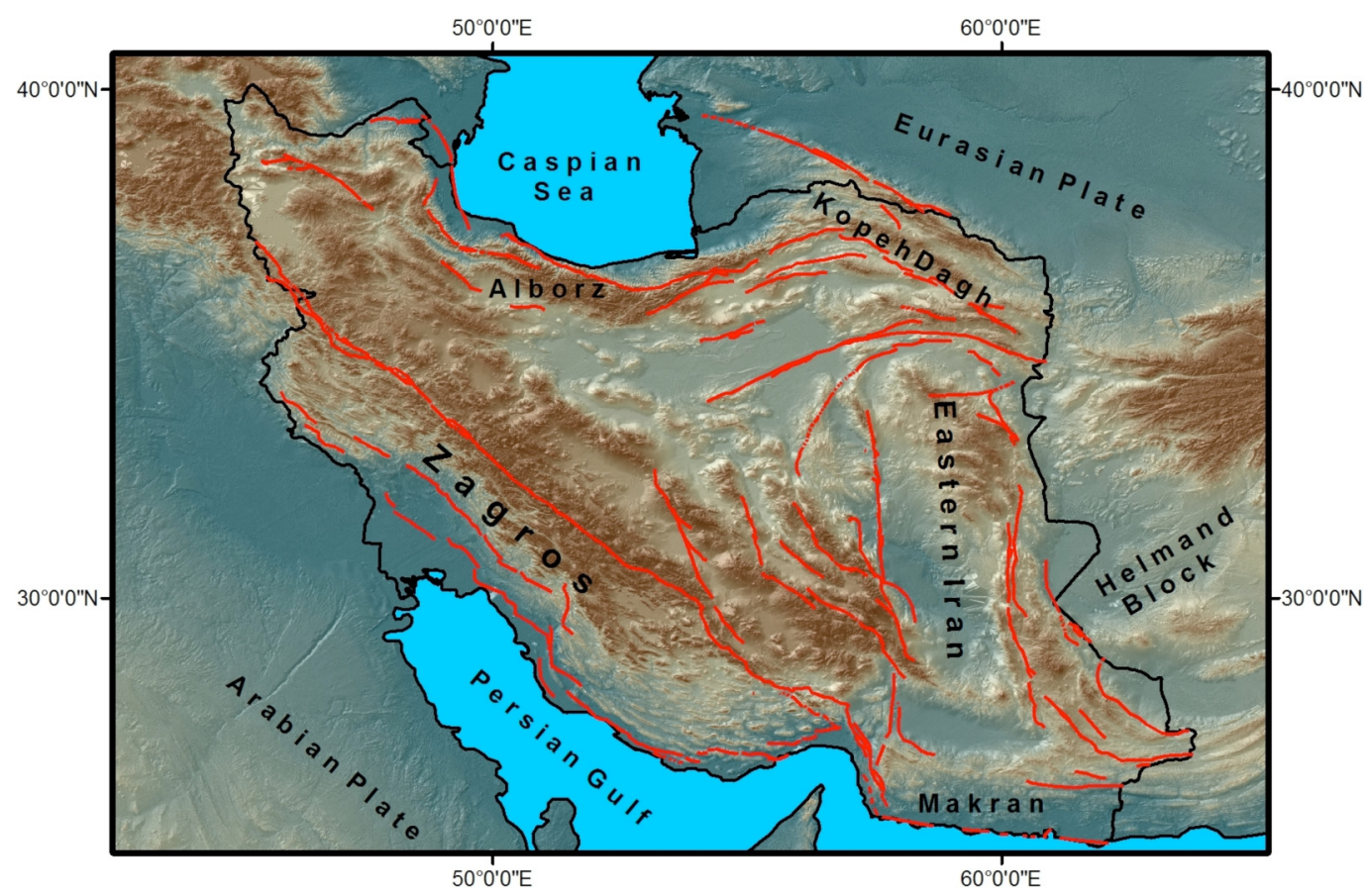

Figure 1. Shaded relief map shows the location of Iran in the Iranian Plateau.

much larger than in the regions where small earthquakes occur [Bus et al. 2009].

The short-term deformation is contributed to the earthquake-related deformation, while the long-term deformation is related to the mountain building processes [Klotz et al. 2006]. Also, the GPS-derived deformation includes transient elastic deformation related to the earthquakes, which present a short-term deformation [Khazardze and Klotz 2003]. Yang and Liu [2010] compared the geologically derived crustal motion with the short-term deformation model constrained by the GPS data in the southwestern United States. They showed that the driving forces for the short-term crustal deformation as measured by the GPS differ from those constrained by the geologically reconstructed long-term crustal deformation. The GPS measurements of 1999-2001in Iran and northern Oman provide new velocity data to quantify the present day plate motions in the Middle East [Vernant et al. 2004].

The short-term seismic deformation in this study is estimated using the instrumental (post-1976) catalog from the Global Centroid Moment Tensor (GCMT) (see Data and resources section). This catalog includes the high accuracy seismic moment tensor components that constrained using the seismic waves and are used to calculate the short-term seismic crustal deformation. Masson et al. [2005] suggested that the direction of the seismic strain rate tensor could be determined using the instrumental seismicity catalogs. Long-term seismic deformation, according to Masson et al. [2005], is constrained using the instrumental and historical (pre1900) catalogs in which the empirical relationships are essential for estimation.

Unlike the instrumental catalogs, historical ones include the pre-1900 earthquakes. Theses catalogs suffer from several uncertainties that can dramatically effect on the seismic moment and then on the seismic strain rates. For example, the epicentral locations of the historical earthquakes and the empirical relations between their intensity, magnitude and seismic moment have large uncertainty. A few number of historical earthquakes are inappropriate for calculate the seismic strain rate. Also, the fault features may be eroded and changed during the hundreds of years.

According to the mentioned reasons, it is not necessary to use the inaccurate and uncertain historical catalogs and their empirical relations to estimate the seismic deformation, because they add more errors into the results and interpretations. Therefore, we decide to compare the short-term seismic crustal deformation, using the instrumental catalog, with the short-term GPS measurements to find reasonable relationships between them and infer the solid earth deformation.

It is applied for estimation of the short-term seismic crustal deformation that requires the knowledge of both the fault plane solution and the seismic moment for each earthquake [Tselentis and Makropoulos 1986, Jackson and McKenzie 1988, Ekstrom and England 1989, Papazachos and Kirtzi 1992]. The focal mechanism solutions provide fundamental information about the tectonic processes in the seismogenic regions [Vamvakaris et al. 2006]. Figure 2 shows the focal mechanisms of the earthquakes that occurred during the period of 1976-2013 in the target areas. The moment tensors, 


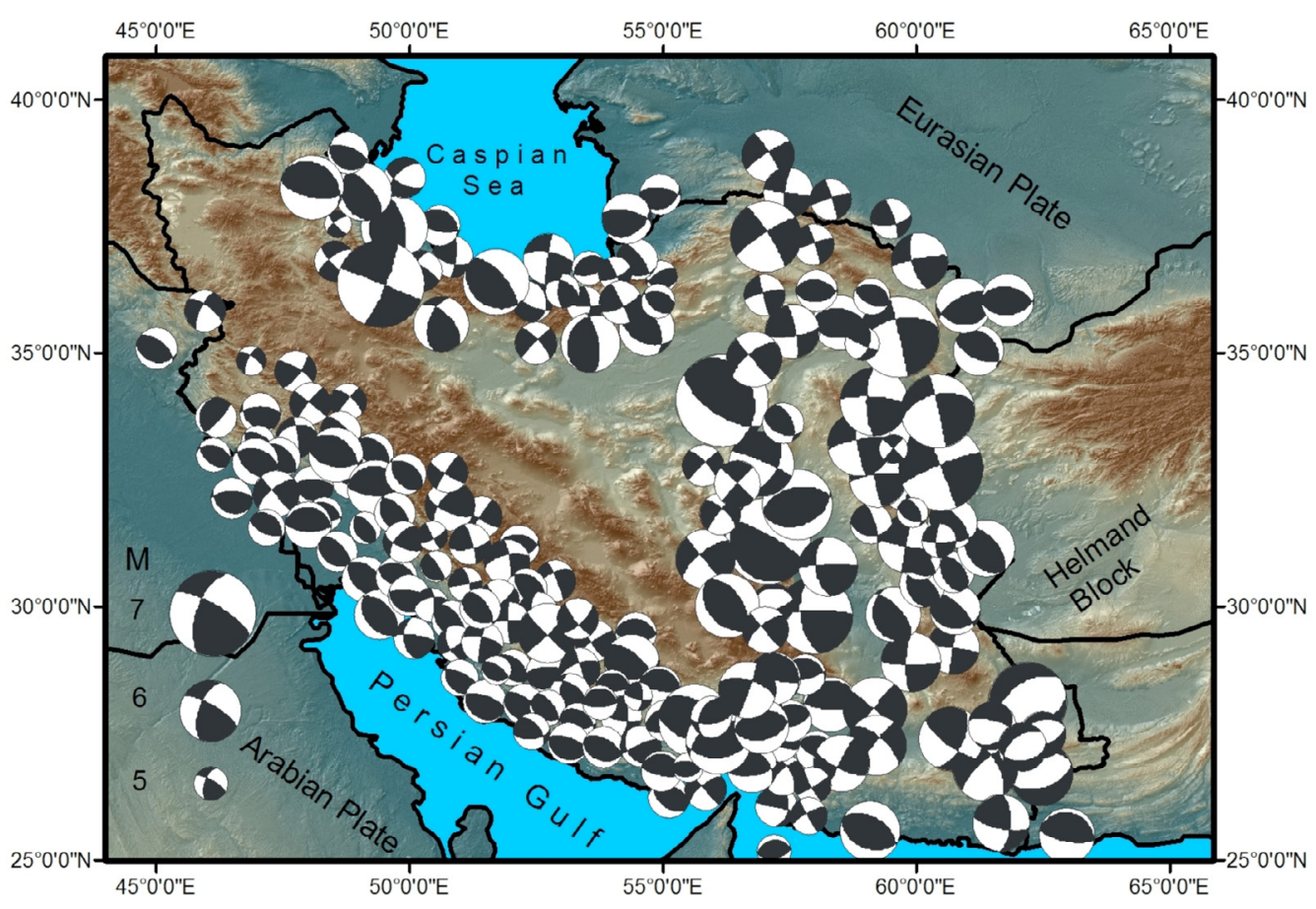

Figure 2. The focal mechanisms of the earthquakes occurred during the period of 1976-2008. The selected earthquakes are obtained from the Global Centroid Moment Tensor (GCMT) catalogue.

which are related to the size of the corresponding earthquakes, can be used to determine the crustal deformation of a seismogenic volume [Kostrov 1974, Jackson and McKenzie 1988, Ward 1998a,b, Qin et al. 2002].

Jackson and McKenzie [1988] estimated the seismic deformation for the Alborz, Kopeh-Dagh, eastern Iran and Zagros orogenic belts using the 70 year's data. These authors only used 17 and 30 earthquakes to estimate the seismic deformation for the whole Zagros and for the whole Alborz, Kopeh-Dagh and eastern Iran orogenic belts, respectively. Nearly, two-thirds of their data was pre-1976. They only used 20 years' data for estimation the a-b values and suggested that the 70 years' seismicity is representative of longer periods, while Masson et al. [2005] proposed that a few earthquakes recorded over a short period may not be representative strain direction and intensity over a much longer timescale. The scalar moment, $\mathrm{M}_{\mathrm{o}}$, in the Jackson and McKenzie's data was obtained from the empirical relation $\left(\mathrm{M}_{\mathrm{o}}-\mathrm{M}_{\mathrm{s}}\right)$. They did not divide the Zagros orogenic belt into the several boxes, whereas the seismicity, tectonic processes, crustal thickness and seismic shortening rate in some parts of the Zagros are different from the other parts. We will discuss that the shortening rate in this orogenic belt increases from NW to SE.

Jackson and McKenzie [1988] also considered the Alborz, Kopeh-Dagh and eastern Iran as a one zone, while the earthquake mechanisms, seismicity and tectonic processes in these regions are different from each other. For example, the dominant fault mechanism in the Kopeh-Dagh (right-lateral motion) is different from the Alborz and eastern Iran (left-lateral motion). We will discuss in detail in the following sections that the Kopeh-Dagh has dominantly an aseismic deformation while Jackson and McKenzie [1988] and Masson et al. [2005] believed that this region has the high seismic deformation.

The objectives of this paper are to determine the rates and orientations of the short-term seismic deformation and estimate the mean directions of the compressional and tensional axes ( $\mathrm{P}$ and $\mathrm{T}$ axes) in the study areas. The orientations of the seismic and geodetic shortening will be compared with each other and with the $\mathrm{P}$ axes ones. In this study we will state exhaustively the seismic deformation percentages of the target regions and compare them with the previous studies. We are going to compare the seismic shortening rate with the maximum shear strain rate. The dominant and nondominant fault mechanisms and tectonic processes of each zone will be determined using the average strain rate tensor, velocity tensor and dilatation rate. Finally, by summation the seismic moment tensor components of the earthquakes, Gutenberg-Richter and momentmagnitude relations, we will determine the seismic moment rate (which describes the size of deformation) in the study areas. The earthquake moment tensors in this paper are selected from the GCMT catalog for the period of 1976-2013. We delineate the deformation zones into 7 regions (zones) with characteristic fault patterns and seismotectonic structures that selected not based upon GPS benchmarks but based on the spatial distribution and focal mechanisms of the earthquakes to 


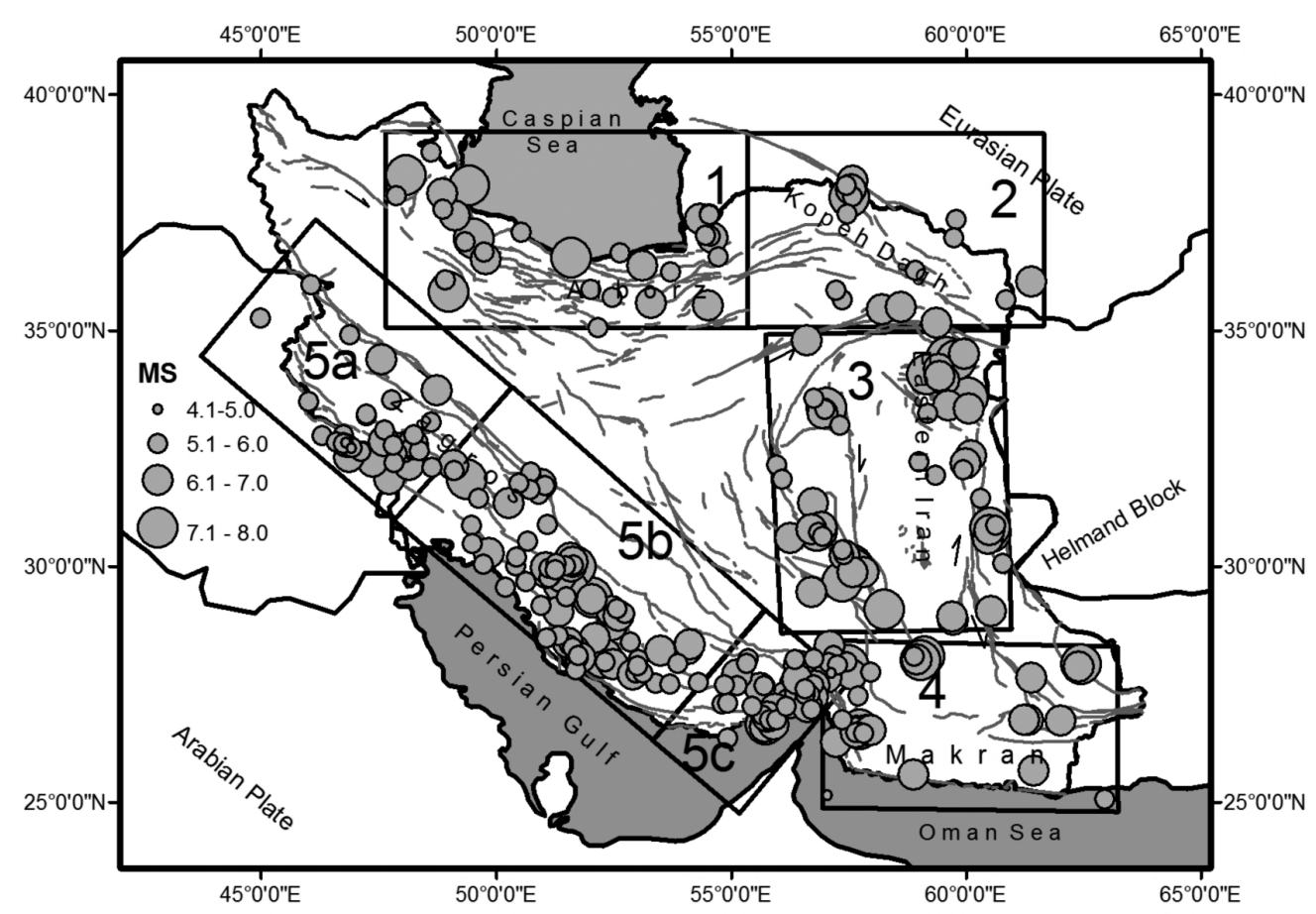

Figure 3. Location map showing the orogenic belts in which seismic deformation is determined [1]; Alborz [2]; Kopeh-Dagh [3] eastern Iran [4]; Makran [5a, 5b, 5c]; Zagros.

avoid overlapping of different style of deformation.

The study areas in this paper comprise the Alborz (1), Kopeh-Dagh (2), eastern Iran (3), Makran (4) and Zagros (5a, 5b and 5c) orogenic belts (Figure 3). There are intersections between several orogenic belts, such as Makran and SE Zagros. Following Bressan et al. [2003], computation of the seismic deformation is weighted on the seismic moment tensor of earthquakes that occurring in the considered volume and this weight increases with increasing magnitude. Therefore, if earthquakes do not occur in the intersections between two zones, the interpretation of the earthquake seismic moment tensors would not confront with the problems. In the intersection between the SE Zagros and Makran orogenic belt, there are not many earthquakes except two small ones.

\section{Tectonic setting}

\section{Alborz}

The Alborz forms a high arc of mountains from $49^{\circ} \mathrm{E}$ to $56^{\circ} \mathrm{E}$ [Jackson et al. 2002]. The Alborz orogenic belt is an excellent example of coeval strike-slip and compressional deformation [Allen et al. 2003]. Most of the focal mechanisms in this belt show either reverse faulting or left lateral strike-slip on faults parallel to the regional strike of the belt [Jackson et al. 2002].

The northward convergence of central Iran toward Eurasia and the NW movement of the southern Caspian Basin with respect to Eurasia influenced these mountain ranges. These motions give rise to a NNE-
SSW transpressional regime in these mountains except in the central Alborz, where a young and active transtensional regime with a WNW-ESE extensional axis exists [Ritz et al. 2006, Jafari 2007]. Vernant et al. [2004] suggested that the geodetic shortening rate of the Alborz is nearly $8 \mathrm{~mm} / \mathrm{yr}$.

\section{Kopeh-Dagh}

The Kopeh-Dagh orogenic belt is oriented $120^{\circ} \mathrm{N}$ with a length of $700 \mathrm{~km}$; it is an active structure that stretches from the Caspian Sea along the Turkmenistan border (Eurasian plate), to Afghanistan [Zamani et al. 2008].

The results of the free-air gravity anomalies show a depression characteristic of the bending in a foreland basin that whereby the Kopeh-Dagh mountain ranges had been thrusted over the Eurasian plate [Hollingsworth et al. 2006].

The earthquakes in the Kopeh-Dagh involve mostly right-lateral strike-slip faults with $\mathrm{N}$ to NNW-trending or reverse faulting parallel to the NW of the regional strike [Falcon 1969, 1974, Tchalenko 1975, Berberian 1981, Jackson and McKenzie 1984, Jackson et al. 2002]. The geodetic shortening rate in this area is about 6 $\mathrm{mm} / \mathrm{yr}$ [Vernant et al. 2004].

\section{Eastern Iran}

The combination of the dominant E-W left-lateral faults and the subordinate N-S right-lateral strike-slip faults with thrust faults trending NW-SE indicates that the eastern part of the Iranian plateau is undergoing a 
structural rotation [Sobouti and Arkani-Hamed 1996]. The northward transition from N-S strike-slip to diffuse thrusting, probably results from the more regional change to E-W left-lateral faulting farther north. The accommodation of N-S right-lateral shear on E-W leftlateral structures require clockwise vertical axis rotation, which in turn results either in shortening across the strike-slip faults themselves, or in diffuse deformation of intervening crustal material [Walker and Khatib 2006]. The mean geodetic shortening rate of this region is nearly $9 \mathrm{~mm} / \mathrm{yr}$ [Vernant et al. 2004].

\section{Makran}

The Makran accretionary prism is the part of the Alpine-Himalayan mountain chain that extends about $1000 \mathrm{~km}$ from $57^{\circ} 30^{\prime} \mathrm{E}$ to $66^{\circ} 30^{\prime} \mathrm{E}$ [Barzi and Talbot 2003, Grando and McClay 2007]. Its frontal thrust is located about $70 \mathrm{~km}$ seaward. The onset of this subduction of an oceanic part of the Arabian Plate beneath Eurasia is estimated to Palaeogene times, while accretion started during Eocene times. The modern accretionary prism has developed since late Miocene and is still propagating seaward [Peyret et al. 2009].

The present-day seismicity of the Makran is low. The large magnitude events are related to the down going plate at the intermediate depths or to the superficial large historical earthquakes in the eastern Makran [Bayer et al. 2006]. Deeper (>60 km), normal faulting events occur further landward likely within the subducting plate. A swarm of strike-slip events occurred further landward from 1978 to 1980 [Byrne et al. 1992, Smith et al. 2012].

The geodetic shortening rate of the Makran is about $19 \mathrm{~mm} / \mathrm{yr}$ as estimated by Vernant et al. [2004].

\section{Zagros}

The Zagros orogenic belt is about $1500 \mathrm{~km}$ long with a $250-400 \mathrm{~km}$ wide. It runs from the eastern Turkey to the Oman Gulf, where it dies out at the Makran subduction zone [Tatar et al. 2002]. The Zagros orogenic belt forms a prominent tectono-stratigraphic unit in the southwest of Iran [Talebian and Jackson 2004]. The Zagros orogenic belt consist $6-15 \mathrm{~km}$ thick sedimentary pile that overlies on the Precambrian metamorphic basement [McCall 1997, Regard et al. 2010].

The crustal shortening in the Zagros shows a transfer of strain from the predominant longitudinal pure thrust-slip to the occasional transverse pure rightlateral slip [Berberian 1995]. The convergence velocity accommodated by the Zagros collision increases progressively from NW to SE [Regard et al. 2010].

The large magnitude earthquakes are restricted to the SW of the Zagros topography [Hatzfeld et al. 2010].
The SE Zagros shows very intense but low magnitude seismicity [Bayer et al. 2006]. Vernant et al. [2004] suggested that the geodetic shortening rate for the NW, central and SE of the Zagros are about 4, 7 and 9 $\mathrm{mm} / \mathrm{yr}$, respectively.

\section{Method of analysis}

The method of analysis followed here is one proposed by Papazachos and Kiratzi [1992] which is based on the formulation of Kostrov [1974], Jackson and McKenzie [1988] and Molnar [1979]:

The equation of Kostrov [1974], Kostrov and Das [1988] and Jackson and MacKenzie [1988] for the seismic strain and average seismic strain rate are:

$$
\begin{gathered}
\varepsilon_{i j}=\frac{1}{2 \mu V} \sum_{n=1}^{N} M_{i j}^{n} \\
\dot{\bar{\varepsilon}}=\frac{1}{2 \mu V t} \sum_{n=1}^{N} M_{i j}^{n}
\end{gathered}
$$

where $M_{i j}^{n}$, are the elements of the moment tensor of the $n$th earthquake out of $\mathrm{N}$ earthquakes which occurred over a time interval $t, \mu$ is the shear modulus $\left(3 \times 10^{10} \mathrm{~N} / \mathrm{m}^{2}\right), V$ is the seismogenic volume which is considered to be a rectangular cube with length, $L_{1}$, width, $L_{2}$, and the thickness of seismogenic layer, $L_{3}[\mathrm{~Pa}$ pazachos and Kiratzi 1992, 1996]. Stephen and Singh [2004] proposed that the average earthquake focal depths can be defined the thickness of the seismogenic layer.

The elements of $M_{i j}^{n}$ can be calculated using the relation:

$$
M_{i j}^{n}=M_{0}^{n}\left(u_{i} n_{j}+n_{i} u_{j}\right)
$$

where $M_{0}$ is the scalar moment and $u$ and $n$ are unit vectors in the direction of the slip vector and the normal to the fault plane, respectively [Kiratzi 1991, Papazachos and Kiratzi 1992].

The P-T axes, following Singh [2000] and Bressan et al. [2003], of the moment tensors of the earthquakes occurring in each target region must be plotted on the equal area lower hemisphere and then must be averaged to estimate their mean directions.

To examine the $3 \mathrm{D}$ deformation style, the strain rates are represented by quantities that reflect the intensity and style of deformation for both vertical and horizontal planes. In this aim, the maximum shear strain and dilatation rates are estimated. The maximum shear strain rate is defined by $\gamma=\left|\dot{\varepsilon}_{\max }-\dot{\varepsilon}_{\min }\right|$ where $\dot{\varepsilon}_{\text {max }}$ is the largest and $\dot{\varepsilon}_{\text {min }}$ is the smallest principle strain rates, respectively, in vertical or horizontal planes. $\dot{\varepsilon}_{\text {max }}$, in practice is $\dot{\varepsilon}_{2}$ or $\dot{\varepsilon}_{3}$ and $\dot{\varepsilon}_{\text {min }}$ is generally $\dot{\varepsilon}_{1} \cdot \gamma$ is a proxy for the intensity of deformation. The dilatation rate is defined as 

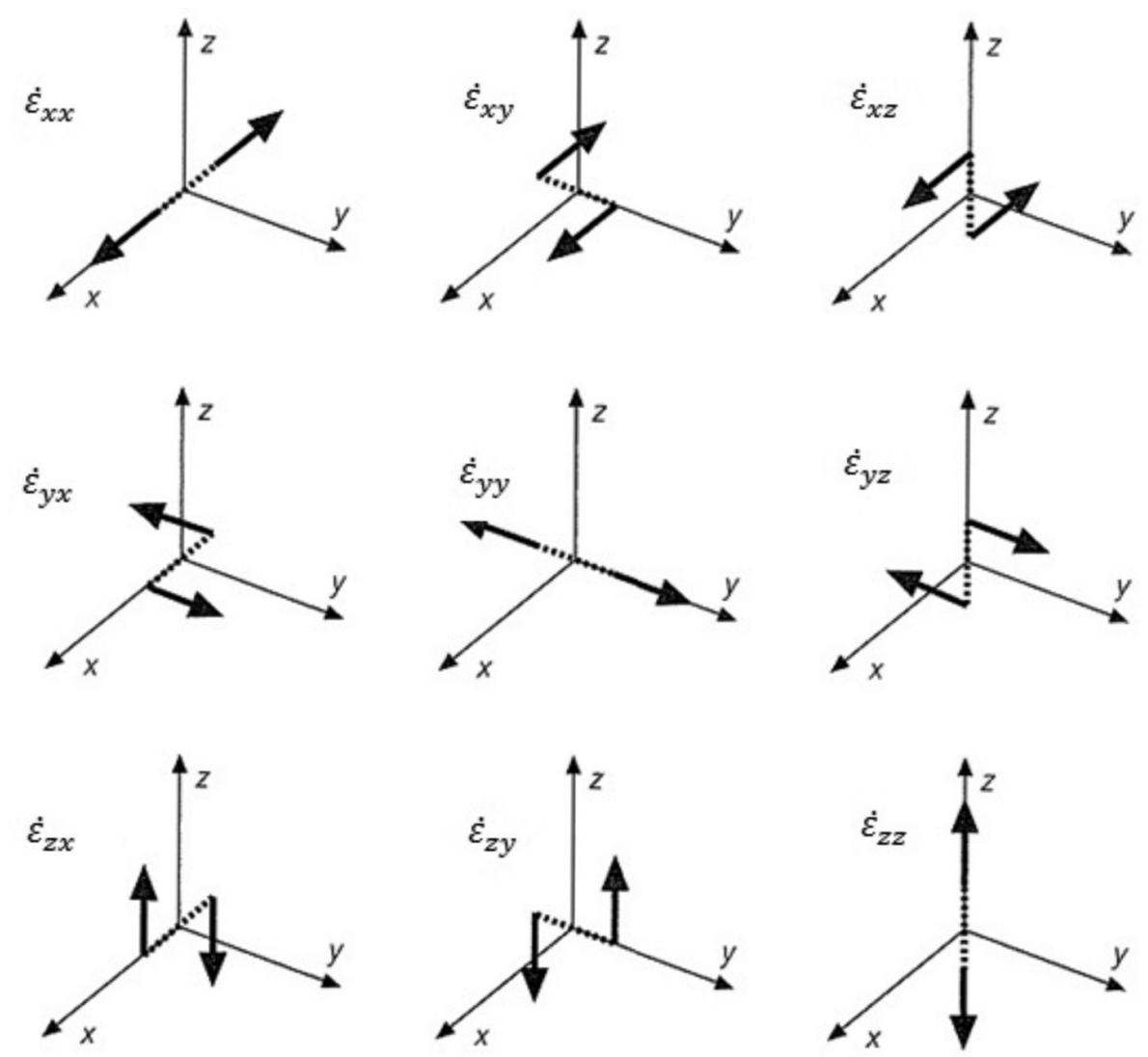

Figure 4. Description of the positive components of the seismic strain rate tensors (modified after Stein and Wysession [2003]). $\mathrm{xx}=(\mathrm{north}-$ south extension) north and south sides move apart; $\mathrm{xy}=$ east side moves north relative to west; $\mathrm{xz}=$ bottom moves north relative to top; $\mathrm{yx}=$ north moves east relative to south; $\mathrm{yy}=$ (east-west extension) east and west sides moves apart; $\mathrm{yz}=$ bottom moves east relative to top; $\mathrm{zx}=$ north moves down relative to south; $z y=$ east moves down relative to west; $z z=$ (vertical thickening) bottom moves apart from top [Wesnousky et al. 1984].

$$
\Delta=\frac{\left(\dot{\varepsilon}_{\max }-\dot{\varepsilon}_{\min }\right)}{2}
$$

with the same convention as maximum shear strain rate. When $\Delta$ is positive, the deformation in the cell is performed by elongation or area expansion. On the contrary, as $\Delta$ becomes negative, the deformation is contractional. When elongation tends to compensate contraction, $\Delta$ approaches zero. Together with the orientation of the principal strain axes these quantities fully describe the strain rate field [Mouthereau et al. 2009].

Jackson and McKenzie [1988] discovered the relationship between the average strain rate and relative velocity between two plates by examining the deformation of the volume $V$. This volume has rectangular faces. In general, there is a difference in the velocity of the material between each of the opposite faces of the volume $V$. According to Papazachos and Kiratzi [1992] velocity tensor can be obtained by the following relations:

$$
\begin{gathered}
V_{i i}=\frac{1}{2 \mu t L_{j} L_{k}} \sum_{n=1}^{N} M_{i i}^{n} i=1,2,3 k \neq j, i \neq k, j \neq i \\
V_{12}=\frac{1}{\mu t L_{1} L_{3}} \sum_{n=1}^{N} M_{12}^{n}
\end{gathered}
$$

$$
V_{i 3}=\frac{1}{\mu t L_{1} L_{2}} \sum_{n=1}^{N} M_{i 3}^{n} \quad i=1,2 .
$$

The sign convention of the velocity, strain and strain rate is as follows. For the components perpendicular to the box faces (xx, yy, $\mathrm{zz}$ ) the positive values represent an extension (for horizontal component) or thickening (for vertical component), and the negative values represent compression (for horizontal component) or thinning (for vertical component). For the strike-slip components (xy), the positive values represent dextral motion and the negative values represent sinistral motion [Pondrelli et al. 1995]. The schematic illustration of the sign conventions of the strain rate tensors is represented in Figure 4. Kiratzi [1994] proposed that the compressive eigenvalue of the velocity tensor indicates the rate of shortening. The directions of the shortening in all of the regions in this study are determined by the direction cosine of the velocity tensor's eigenvectors.

Following Molnar [1979]; Papazachoas and Kiratzi [1992, 1996], the size of the deformation in each seismogenic source is expressed by the annual scalar moment released. In the other word, the seismic moment rate is given by: 


$$
\dot{M}_{0}=\frac{A}{1-B} M_{0 \max }^{(1-B)}
$$

where $M_{0 \max }$ is the moment of the largest event in each source, the A and B are constants that given by:

$$
\begin{gathered}
A=10^{\left(a+\left(\frac{b d}{c}\right)\right)} \\
B=\frac{b}{c}
\end{gathered}
$$

where $a$ and $b$ are the parameters in the GutenbergRichter relation, $\log N=a-b M_{s}, c$ and $d$ are the parameters of the moment-magnitude relation, $\log M_{0}=$ $c M_{s}+d$. According to Kanamori and Anderson [1975], the values of $c$ and $d$ are theoretically equal to $1.5,16$ respectively.

If a seismic zone with $\mathrm{N}$ focal mechanisms which have occurred over a time period, $t$, then the moment tensor of the $n$th event, $M^{n}$, can be represented as:

$$
M^{n}=M_{0}^{n} \cdot F^{n}(\xi, \delta, \lambda)
$$

where $M_{0}^{n}$ is the scalar moment of this event and $F^{n}$ is a shape tensor representing the geometrical features of the earthquake which is a function of the strike, $\xi$, dip, $\delta$, and rake, $\lambda$, of the corresponding fault plane [Aki and Richard 1980, Papazachos and Kiratzi 1996]. By rewriting the Equation (10) for the annual rates of the whole zone, the average shape tensor, $\bar{F}$, (which known as the focal mechanism tensor) will be calculated

$\bar{F}=\frac{\dot{M}}{\dot{M}_{0}}=\frac{\sum_{n=1}^{N} \frac{M^{n}}{t}}{\sum_{n=1}^{N} \frac{M_{0}^{n}}{t}}=\frac{\sum_{n=1}^{N} M^{n}}{\sum_{n=1}^{N} M_{0}^{n}}=\frac{\sum_{n=1}^{N} M_{0}^{n} F^{n}}{\sum_{n=1}^{N} M_{0}^{n}}$

where $\dot{M}$ is the annual moment rate that is given by $M^{n}=M_{0}^{n} \cdot F^{n}$. The focal mechanism tensor is just a moment-normalized tensor; that is, a moment-weighted average of the $F^{n}$ tensors. In practice this means that the large earthquakes control the calculation of $\bar{F}$, sim- ply because of their large scalar moment. In the cases where we have only a few focal mechanisms, if one event has a significantly larger magnitude and slightly different mechanism than the other events, this would mean that $\bar{F}$ would be totally controlled by the corresponding focal mechanism [Kiratzi and Papazachos 1995]. The focal mechanism tensor is calculated from the available fault plane solutions, regardless of their completeness, since $\bar{F}$ is independent of time, t [Papazachoas and Kiratzi 1992, 1996]. In Equation (11), $t$ is omitted from the numerator and denominator. Therefore, it would be estimated from the available earthquakes.

Guzmán-Speziale et al. [2006] proposed that this tensor is simply the average sum of normalized seismic moment tensors that can be written as follows:

$$
\bar{F}_{i j}=\frac{1}{N} \frac{\sum_{n=1}^{N} M_{i j}^{n}}{\sum_{n=1}^{N} M_{0}^{n}}
$$

One way to check whether the focal mechanisms in an area are consistent with one another is to see the deviation of the eigenvalues of the mean tensor, $\bar{F}$, from the ideal double couple values [Papazachos and Kiratzi 1996]. For a double couple source the intermediate principal moment is always zero, and the other two principal moments are equal and opposite $(+1$ and $-1)$ in value [Frohlich and Apperson 1992]. Therefore, if all fault plane solutions within a region are identical, then the eigenvalues of $\bar{F}$, should be $+1,0,-1$ [Kiratzi 1993, 1994].

\section{Results and discussion}

The characteristics of the study areas, Gutenberg-

\begin{tabular}{|c|c|c|c|c|c|c|c|c|c|c|}
\hline Zones & $\begin{array}{c}L_{1} \\
(\mathrm{~km})\end{array}$ & $\begin{array}{c}L_{2} \\
(\mathrm{~km})\end{array}$ & $\begin{array}{c}L_{3} \\
(\mathrm{~km})\end{array}$ & $\begin{array}{c}t \\
\text { (year) }\end{array}$ & $N$ & $a$ & $b$ & M & $\mathrm{P}$-axis & T-axis \\
\hline 1 & 690 & 460 & 19 & 35 & 30 & 7.41 & 1.09 & $4.5-7.7$ & 30 & 113 \\
\hline 2 & 560 & 460 & 23 & 27 & 16 & 7.59 & 1.16 & $4.5-6.8$ & 27 & 119 \\
\hline 3 & 700 & 470 & 18 & 37 & 51 & 5.80 & 0.736 & $4.1-7.4$ & 35 & 121 \\
\hline 4 & 615 & 380 & 28 & 34 & 39 & 7.10 & 1.03 & $4.5-6.5$ & 24 & 152 \\
\hline $5 a$ & 550 & 390 & 20 & 36 & 39 & 7.88 & 1.21 & $4.5-6$ & 26 & 108 \\
\hline $5 b$ & 740 & 390 & 23 & 37 & 78 & 7.48 & 1.18 & $4.3-6.8$ & 29 & 117 \\
\hline $5 c$ & 250 & 390 & 18 & 36 & 42 & 8.26 & 1.28 & $4.7-6.9$ & 177 & 112 \\
\hline
\end{tabular}
Richter relation and the mean directions of the $\mathrm{P}$ and $\mathrm{T}$ axes are represented in Table 1. Figure 5 shows the frequency-magnitude relation for the studied regions. The $a-b$ values in this study are estimated from the Engdahl

Table 1. Length $\left(L_{1}\right)$, width $\left(L_{2}\right)$, seismogenic thickness $\left(L_{3}\right)$, number of events $(N)$, time period $(t), a$ and $b$ values, magnitude range $(\mathrm{M})$ and trend of the $\mathrm{P}$ and $\mathrm{T}$ axes in the study areas. 

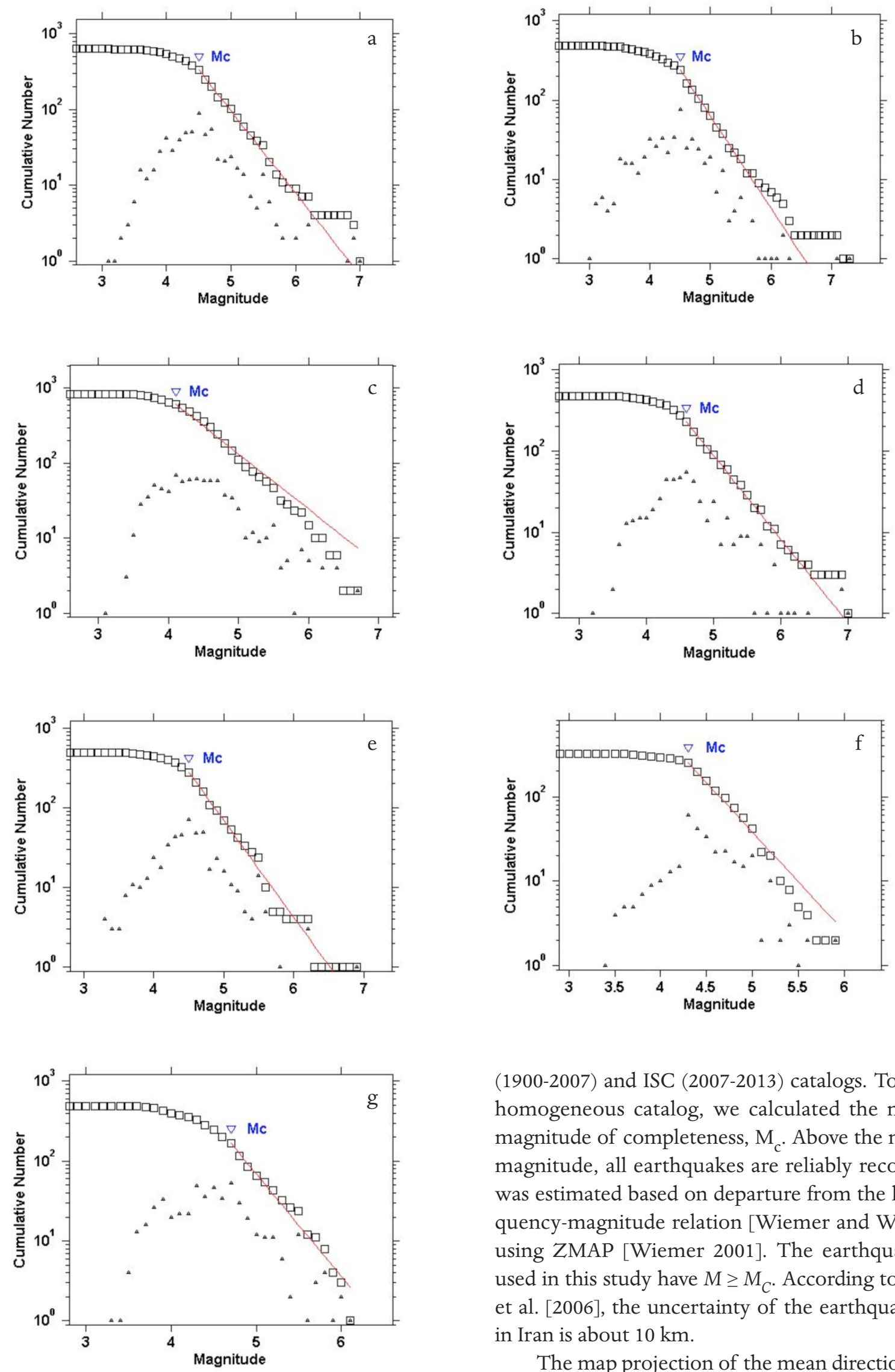

Figure 5. The frequency-magnitude relation and the minimum magnitude of completeness $\left(\mathrm{M}_{\mathrm{c}}\right)$ of the earthquakes occurred in the selected regions that are obtained from the Engdahl's catalog. [a]; Alborz [b]; Kopeh-Dagh [c]; eastern Iran [d]; Makran [e, f, g]; NW-central- SE Zagros, respectively.

(1900-2007) and ISC (2007-2013) catalogs. To certify a homogeneous catalog, we calculated the minimum magnitude of completeness, $M_{c}$. Above the minimum magnitude, all earthquakes are reliably recorded. $M_{c}$ was estimated based on departure from the linear frequency-magnitude relation [Wiemer and Wyss 2000] using ZMAP [Wiemer 2001]. The earthquakes that used in this study have $M \geq M_{C}$. According to Engdahl et al. [2006], the uncertainty of the earthquake depth in Iran is about $10 \mathrm{~km}$.

The map projection of the mean directions of the $\mathrm{P}$ and $\mathrm{T}$ axes are shown in Figure 6. We found that in the regions 1-5b, P-axes were mostly oriented northeast but in the $5 \mathrm{c}, \mathrm{P}$-axis was oriented roughly north-south, as listed in Table 1. The NE orientation of the P-axes is correlated with the oblique shortening due to the Ara- 


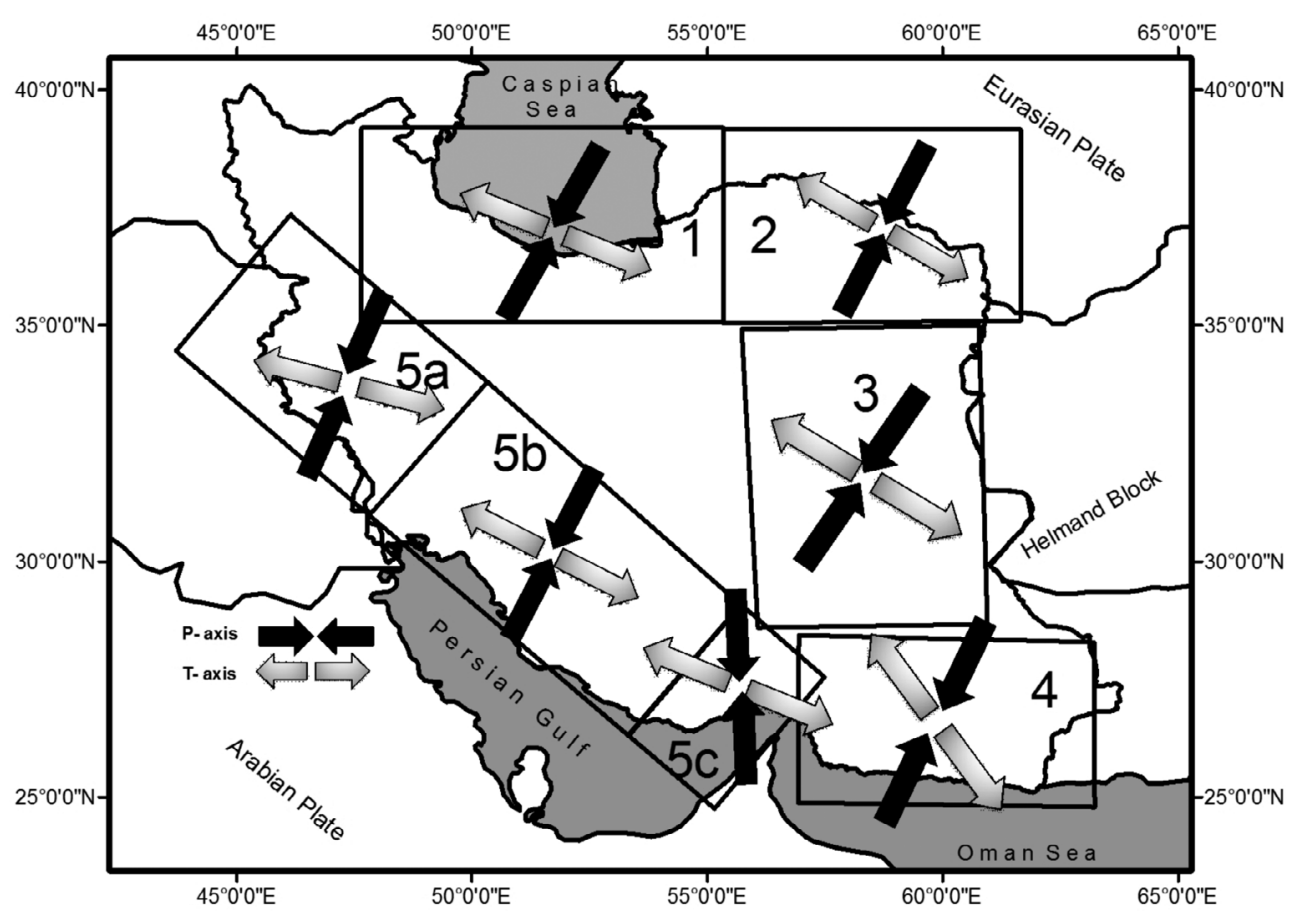

Figure 6. The mean directions of the Compressional and Tensional axes (P-T axes) of the earthquakes.

\begin{tabular}{|c|c|c|c|c|c|c|c|c|c|c|c|c|c|c|c|}
\hline \multirow{2}{*}{ Zones } & \multicolumn{6}{|c|}{ Average strain rate $\left(1 \times 10^{-10} /\right.$ year $)$} & \multicolumn{9}{|c|}{ Eigensystems of the average strain rate $\left(1 \times 10^{-8}\right)$} \\
\hline & $\bar{\varepsilon}_{11}$ & $\bar{\varepsilon}_{22}$ & $\bar{\varepsilon}_{33}$ & $\bar{\varepsilon}_{12}$ & $\bar{\varepsilon}_{13}$ & $\bar{\varepsilon}_{23}$ & $\lambda_{1}$ & $P l$ & $A z$ & $\lambda_{2}$ & $P l$ & $A z$ & $\lambda_{3}$ & $P l$ & $A z$ \\
\hline 1 & 29.7 & 48 & -77.7 & -66.7 & 8.05 & 52.1 & -1.04 & -61 & 63 & -0.08 & 25 & 32 & 1.12 & 12 & 130 \\
\hline 2 & 0.508 & -7.19 & 6.78 & 1.27 & -0.302 & 3.86 & -0.084 & -14 & 95 & 0.007 & -3 & 10 & 0.077 & -75 & 94 \\
\hline 3 & 120 & -116 & -5.10 & -9.9 & -21.7 & 170 & -2.3 & -36 & 90 & 0.96 & 35 & 32 & 1.34 & 34.5 & 150 \\
\hline 4 & -6.44 & 10.4 & 3.5 & 10.8 & 3.16 & 15.6 & -0.155 & -5 & 145 & -0.085 & 57 & 125 & 0.24 & -30 & 118 \\
\hline $5 a$ & 4.68 & -6.9 & 2.23 & 2.16 & -0.218 & 2.50 & -0.079 & -14 & 85 & 0.029 & 75 & 120 & 0.05 & 5.5 & 11.5 \\
\hline $5 b$ & 11.8 & -13.7 & 1.96 & 1.72 & 0.231 & 7.42 & -0.168 & 21.5 & 87 & 0.048 & 68 & 108 & 0.12 & -5 & 175 \\
\hline $5 c$ & 54 & -58 & 38 & 30.8 & 4.6 & -9.15 & -0.671 & -8 & 75 & 0.051 & 82 & 91 & 0.62 & -2 & 166 \\
\hline
\end{tabular}

Table 2. The average seismic strain rate tensors, eigensystems, plunges and azimuths are indicated by $\varepsilon_{i j}, \nu_{i j}, \lambda_{1}, \lambda_{2}, \lambda_{3}, P l$ and $A z$ respectively.

bia-Eurasia collision in the most regions. The N-S orientation is consistent with the orthogonal shortening dominantly in the SE of the Zagros, as suggested by several authors [e.g., Blanc et al. 2003, Talebian and Jackson 2004, Allen et al. 2006, Zarifi et al. 2013].

The components of the average strain rate tensor and their eigensystems are summarized in Table 2 . The sign convention of the compressive eigenvalue $\left(\lambda_{1}\right)$ of the average strain rate tensor in all of the regions indicated that the compression plays an important role in the deformation of the target areas. Kiratzi [1994] pointed out that the positive eigenvalues represented an extension of the horizontal component or thickening for the vertical component, while negative ones represented shortening for the horizontal component or thinning for the vertical component.

The maximum shear strain rate and dilatation rate that were estimated from the eigenvalues of the aver- age strain rate tensors are demonstrated in Table 3. We found that the highest $\gamma$ affected the eastern Iran, Alborz and SE Zagros, while the lowest one affected the NW Zagros, Kopeh-Dagh, central Zagros and Makran, respectively. These results are in good agreement with the results of the seismic shortening rates in the following sections.

The positive dilatation rate indicated that the subordinate extensional regime existed in the selected re-

\begin{tabular}{cccccccc}
\hline & \multicolumn{7}{c}{ Zones } \\
\cline { 2 - 8 } & 1 & 2 & 3 & 4 & $5 \mathrm{a}$ & $5 \mathrm{~b}$ & $5 \mathrm{c}$ \\
\hline$\gamma\left(1 \times 10^{-8}\right)$ & 2.2 & 0.16 & 3.8 & 0.39 & 0.13 & 0.28 & 1.3 \\
$\Delta\left(1 \times 10^{-10}\right)$ & 4 & -0.3 & -48.4 & 4.45 & -1.4 & -2.4 & -2.7 \\
\hline
\end{tabular}

Table 3. Maximum shear strain rates $(\gamma)$ and dilatation rates $(\Delta)$ of the study areas. 
gions. Dilatation rates in the Alborz and Makran orogenic belts were positive, while in the eastern Iran, $\mathrm{Za}$ gros and Kopeh-Dagh orogenic belts were negative. These results are consistent with the studies of several authors, such as Ritz et al. [2006] who proposed that the morphological and structural features observed along the several faults characterized an active transtensional deformation occurring in the internal domain of the central Alborz. Also, the mentioned authors suggested that not only the horizontal movements along the strike-slip faults in the western Alborz, but also the vertical component of the thrust faults in the internal part of the range have been reserved; this is an outstanding example of extensional phenomena occurring within compression-dominated region. Grando and McClay [2007] proposed that since the Middle Pleistocene the coastal part of the Makran has experienced the normal faulting.

The components of the velocity tensor and their eigensystems are listed in the Table 4. According to Papazachos and Kiratzi [1996], the positive and negative values of $V_{33}$ indicated the vertical thickening and thinning of the crust, respectively. $V_{33}$ for the Alborz and eastern Iran were -0.014 and -0.0009 . Then, these regions experienced vertical thinning of the crust and the other regions that have positive values, experienced vertical thickening.

Since the negative and positive values of the $V_{12}$ indicated respectively sinistral and dextral strike-slip motions, we found that the left lateral strike-slip motion only affected the Alborz and eastern Iran, while the right lateral strike-slip motion affected the KopehDagh, Makran and Zagros orogenic belts. These results are in good agreement with the several authors, such as Jackson et al. [2002] who suggested that the earthquakes in the Kopeh-Dagh involve mostly right-lateral strike-slip faulting with $\mathrm{N}$ to NNW trending or reverse faulting parallel to the NW regional strike. Most of the focal mechanisms in the Alborz show either reverse faulting or left-lateral strike-slip on faults parallel to the regional strike of the belt. Talebian and Jackson [2004] pointed out that the NW of the Zagros with a major NW-SE right-lateral strike-slip fault system roughly follows the Zagros Thrust Line for almost $800 \mathrm{~km}$ and the central Zagros associated with the roughly $\mathrm{N}-\mathrm{S}$ rightlateral strike-slip fault system between $51^{\circ}-53^{\circ} \mathrm{E}$.

The rate of the short-term seismic crustal deformation was determined from the compressive eigenvalue $\left(\lambda_{1}\right)$ of the velocity tensor. The orientations of the short-term seismic deformation were defined by the direction cosine of the eigenvector components. The short-term seismic deformation rates for zones 1 , $2,3,4,5 \mathrm{a}, 5 \mathrm{~b}$ and $5 \mathrm{c}$ were about $4.00,0.34,5.50,0.94$, $0.32,0.55$ and $3.45 \mathrm{~mm} /$ year, respectively. Our results in the Zagros orogenic belt indicated that the shortening rate due to the seismic moment tensor summation increased from NW to SE. This is consistent with the previous works published by Nilforoushan et al. [2003], Vernant et al. [2004] and Masson et al. [2007]. We found that the eastern Iran, Alborz and SE Zagross have the highest seismic shortening rates, while the NW Zagros, Kopeh-Dagh, central Zagros and Makran have the lowest ones. These results are compared with Vernant et al. [2004] who measured the geodetic deformation (shortening) rates in Iran (Figure 7). Vernant et al. [2004] proposed that the geodetic deformation rates for the Alborz, Kopeh-Dagh, eastern Iran, Makran and the NW, central and SE Zagros orogenic belts are about $8 \pm 2,6 \pm 2,9 \pm 2,19 \pm 2,4 \pm 2,7 \pm 2$ and $9 \pm 2 \mathrm{~mm} /$ year, respectively. Hessami et al. [2006] suggested that the shortening rate across the NW Zagros is about $5 \pm 3$ $\mathrm{mm} /$ year.

Following Masson et al. [2005], when the amplitude of the seismic deformation rate is the same order as the amplitude of the geodetic deformation rate, the large part of the deformation would be seismic. We have compared the seismic shortening rate in this study with the results of Vernant et al. [2004] and find that in

\begin{tabular}{|c|c|c|c|c|c|c|c|c|c|c|c|c|c|c|c|}
\hline \multirow{2}{*}{ Zones } & \multicolumn{6}{|c|}{ Velocity tensor (cm/year) } & \multicolumn{9}{|c|}{ Eigensystems of the velocity tensor } \\
\hline & $V_{11}$ & $V_{22}$ & $V_{33}$ & $V_{12}$ & $V_{13}$ & $V_{23}$ & $\lambda_{1}$ & $P l$ & $A z$ & $\lambda_{2}$ & $P l$ & $A z$ & $\lambda_{3}$ & $P l$ & $A z$ \\
\hline 1 & 0.2 & 0.22 & -0.014 & -0.61 & 0.0003 & 0.02 & -0.40 & -2 & 45 & -0.12 & 87 & 18 & 0.52 & 1 & 135 \\
\hline 2 & 0.002 & -0.033 & 0.001 & 0.011 & -0.00014 & 0.0018 & -0.034 & -3 & 75 & 0.007 & 83 & 172 & 0.027 & -5 & 165 \\
\hline 3 & 0.843 & -0.544 & -0.0009 & -0.09 & -0.0076 & 0.056 & -0.55 & -5 & 86 & 0.085 & 84 & 78.5 & 0.465 & 1 & 176 \\
\hline 4 & -0.04 & 0.039 & 0.0009 & 0.083 & 0.0017 & 0.0057 & -0.094 & -1 & 33 & -0.001 & 87 & 131 & 0.095 & 3 & 125 \\
\hline $5 a$ & 0.026 & -0.027 & 0.0004 & 0.017 & -0.00008 & 0.0009 & -0.032 & 1.5 & 74 & 0.0008 & 88 & 118 & 0.031 & -1 & 164 \\
\hline $5 b$ & 0.087 & -0.054 & 0.0004 & 0.013 & 0.00009 & 0.0031 & -0.055 & -3 & 83 & 0.006 & 86 & 100 & 0.049 & -0.3 & 175 \\
\hline $5 c$ & 0.136 & -0.226 & 0.0007 & 0.24 & 0.0017 & -0.0033 & -0.345 & -0.5 & 63 & 0.06 & 89 & 71 & 0.285 & 0 & 153 \\
\hline
\end{tabular}

Table 4. The velocity tensors, eigensystems, plunges and azimuths are indicated by $v_{i j}, \lambda_{1}, \lambda_{2}, \lambda_{3}, P l$ and $A z$ respectively. 


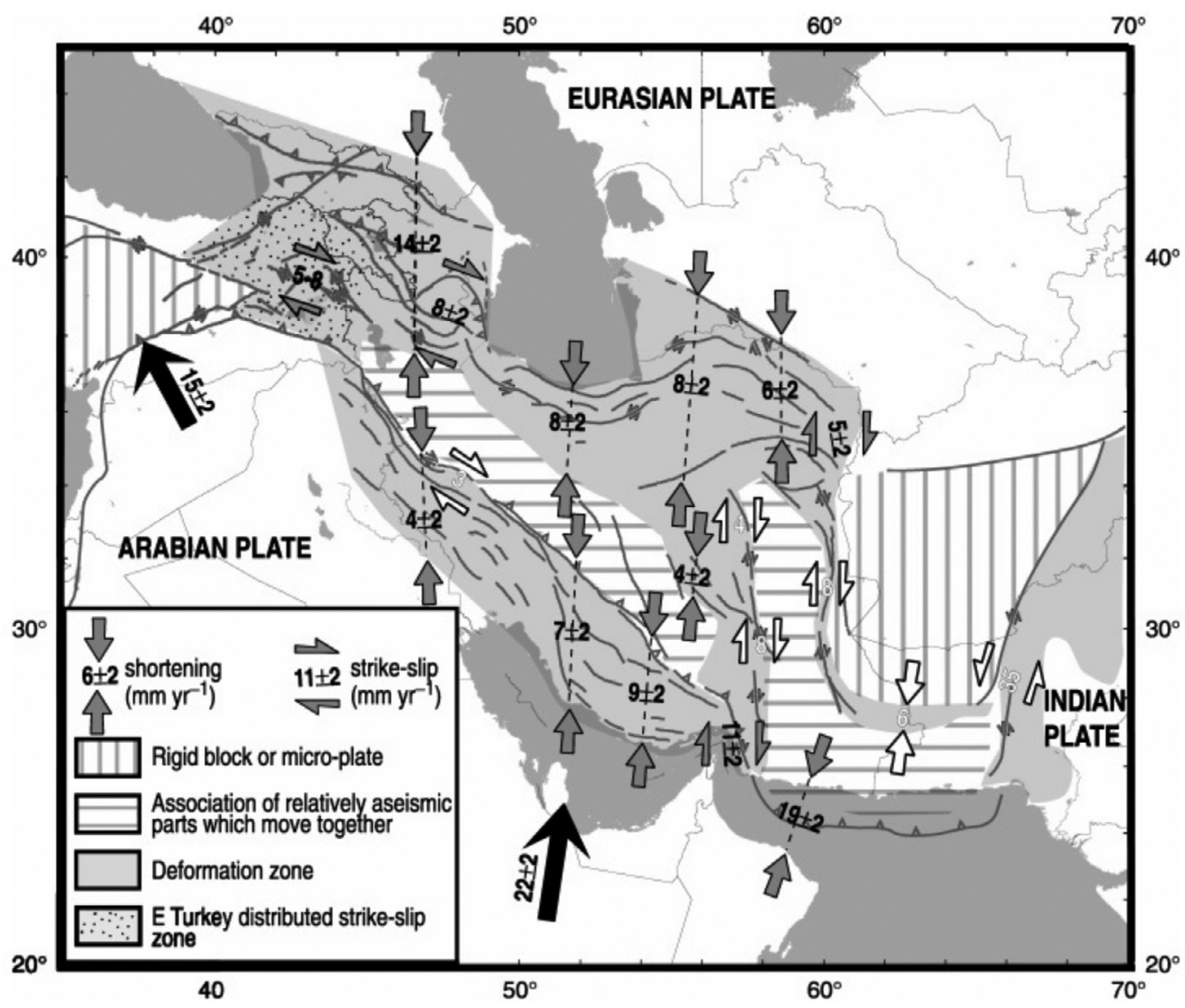

Figure 7. Schematic representation of the geodetic shortening rate $\left(\mathrm{mm} \mathrm{yr}^{-1}\right)$ of Iran [Vernant et al. 2004].

the eastern Iran and Alborz, the amplitude of the seismic shortening rate are almost near the geodetic one, while in the Makran, Zagros and Kopeh-Dagh the amplitude of the seismic shortening rate are far from the geodetic one.

Figure 8 shows the orientations of the short-term seismic crustal deformation. We have compared the directions of the seismic shortening with the directions of the P-axes, were oriented NNE, and discover a difference between them. We perceive that if all of the events that were used in this study have only the thrust mechanism, the directions of the seismic shortening and the P-axes should be about parallel, whereas all of the regions in this study are encompassed with the combination of the strike-slip and thrust-slip mechanisms. In such environments because of lateral translation, one cannot equate the $\mathrm{P}$-axes with the directions of the shortening.

The directions of the seismic shortening in this study have been compared with Vernant's and Masson's. We distinguish that the directions of the seismic shortening in some regions (e.g. Makran, some parts of the Alborz and SE Zagros) have some similarities with the geodetic shortening and in some regions (e.g. KopehDagh and some parts of the NW-central Zagros) have discrepancies. According to Masson et al. [2005], if strain in a region is not homogeneous (i.e. because of unknown faults or blind faults or may be due to faults with varied mechanism), the directions of the seismic and geodetic shortening will be different. We have also detected that the seismic shortening direction of some triangles of the Zagros (triangle 7), Zagros-Makran (triangle 9), Makran (triangle 10), Alborz (triangle 24) and Kopeh-Dagh (triangle 26) orogenic belts that constrained by Masson et al. [2005] have NW striking and are in contrast with this study and the NE plate motion.

We have also compared our results with Zarifi et al. [2013] who, based on the seismic activity between 1909 and 2012 and the geodetic data during 1999-2011, calculated the principle axes of stress and seismic and geodetic strain rates in Iran. We find that the directions of the seismic shortening and the trends of the P-axes in the all regions except the central Alborz, are in good agreement with the results of Zarifi.

We find that the mean directions of the P-axes based on the summation of the seismic moment tensors in some regions of Iran are nearly fitting with the geodetic shortening directions.

The seismic deformation percentage was determined by the ratio of the seismic deformation rate on the geodetic deformation rate. Our results indicated that the percentages of the seismic deformation in the study areas were about 50, 5.5, 61, 5, 8, 7.8 and 38 for the Alborz (1), Kopeh-Dagh (2), eastern Iran (3), 


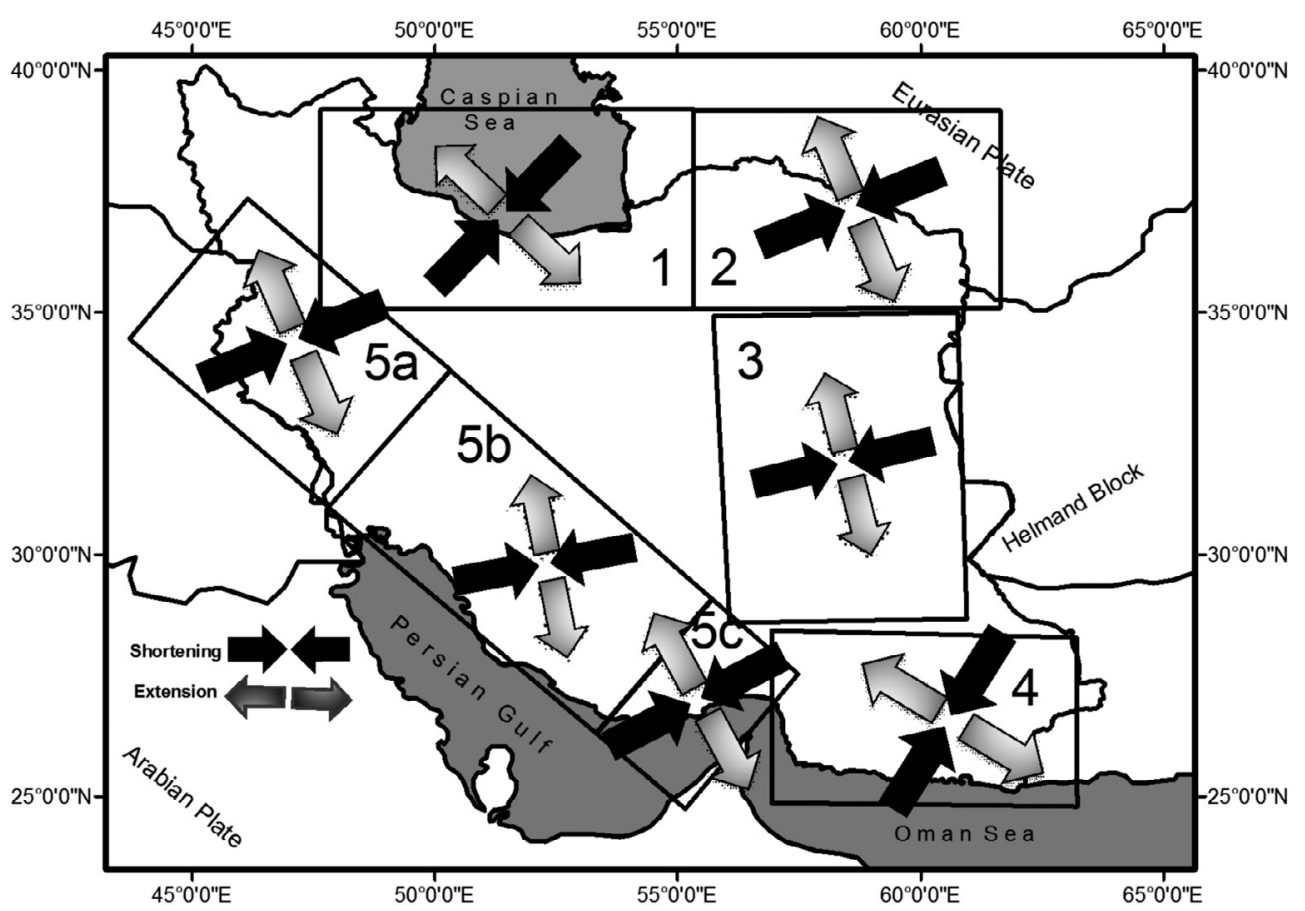

Figure 8. The orientations of seismic deformation of the Iranian regions that are estimated from the direction cosines of the velocity tensors.

Makran (4), and Zagros (5a, 5b, 5c) orogenic belts, respectively. The present results in some cases are on the contrary to the previous studies such as Jackson and McKenzie [1988]. They suggested that the Kopeh-Dagh has the high seismic deformation percentage (50-100\%) same as the Alborz and eastern Iran, while we represented that the Kopeh-Dagh orogenic belt is one of the most aseismic deformation regions in Iran. Jackson and McKenzie [1988] did not calculate the seismic deformation for the Makran and different parts of the Zagros (such as NW and SE of the Zagros separately).

The seismic/geodetic ratio of this paper has also some discrepancies with Masson's. We found that the NW Zagros and Kopeh-Dagh have the high aseismic deformation, while Masson et al. [2005] based on the recent 100 years earthquakes suggested that the NW Zagros and Kopeh-Dagh have the large seismic deformation ( $171 \%$ and $97 \%$, respectively). We calculated that the Alborz orogenic belt has 50\% seismic deformation, while Masson et al. [2005] proposed a very high percentage ( $176 \%$, about 3 times of ours). There are big discrepancies among the percentages of the seismic/geodetic ratio of Masson in the neighbor triangles of the Alborz (461\% for the triangle 19, 0\% for the triangle $20,59 \%$ for triangle 21 and $8 \%$ for the triangle 23 ). We estimated that the eastern Iran has the most seismic deformation percentage, while Masson et al. [2005] suggested that around the eastern Iran the seismic strain rate decreased on considering a larger historical period. Also their results about the seismic/geodetic ratio in the adjacent triangles (28 and 30) in the eastern Iran have large discrepancies ( $8 \%$ and $174 \%$, respectively).

We detected that the SE Zagros has the most seismic deformation percentage among the other parts of the Zagros orogenic belt. This is in agreement with Zarifi et al. [2013] who suggested that the main active

\begin{tabular}{|c|c|c|c|c|c|c|c|c|c|}
\hline \multirow{2}{*}{ Zones } & \multicolumn{6}{|c|}{ Average shape tensor } & \multicolumn{3}{|c|}{ Eigenvalues } \\
\hline & $\bar{F}_{11}$ & $\bar{F}_{22}$ & $\bar{F}_{33}$ & $\bar{F}_{12}$ & $\bar{F}_{13}$ & $\bar{F}_{23}$ & $\lambda_{1}$ & $\lambda_{2}$ & $\lambda_{3}$ \\
\hline 1 & 0.0076 & 0.012 & -0.02 & -0.017 & 0.0002 & 0.013 & -0.0254 & -0.0035 & 0.0289 \\
\hline 2 & 0.0034 & -0.049 & 0.046 & 0.0086 & -0.002 & 0.0261 & -0.057 & 0.005 & 0.052 \\
\hline 3 & 0.0074 & -0.0007 & -0.0003 & -0.0006 & -0.0013 & 0.01 & -0.0171 & 0.007 & 0.0102 \\
\hline 4 & -0.005 & 0.0075 & 0.0025 & 0.0078 & 0.0023 & 0.0076 & -0.0091 & -0.0057 & 0.0148 \\
\hline $5 \mathrm{a}$ & -0.013 & -0.019 & 0.0061 & 0.006 & 0.0006 & 0.007 & -0.0061 & -0.002 & 0.0081 \\
\hline $5 b$ & 0.0064 & -0.0074 & 0.001 & 0.0009 & 0.00012 & 0.004 & -0.009 & 0.0025 & 0.0065 \\
\hline $5 c$ & 0.0179 & -0.019 & 0.0012 & 0.01 & 0.0015 & -0.003 & -0.022 & 0.002 & 0.02 \\
\hline
\end{tabular}

Table 5. Average shape tensors and their eigenvalues indicated by $F_{i j}, \lambda_{1}, \lambda_{2}, \lambda_{3}$, respectively. 
shortening is observed in the southeastern part of the Zagros, while less shortening is observed in the northwestern part.

The average shape tensors and their eigenvalues are listed in Table 5. From the eigenvalues of the average shape tensors one can infer that the Kopeh-Dagh has the most similarity of the earthquake focal mechanisms, whereas in the other regions the focal mechanisms are different.

Table 6 shows the calculated seismic moment rate and parameters $\mathrm{A}$ and $\mathrm{B}$ in the target regions. The seismic moment rate indicates the size of deformation. The zones affected by the highest seismic moment rates are respectively the eastern Iran, Alborz, Makran, SE Zagros, Kopeh-Dagh, NW and central of the Zagros orogenic belts. These regions are approximately similar to the regions that the seismic shortening rates are estimated.

\section{Conclusion}

The short-term seismic crustal deformation is evaluated by the instrumental catalog. The mean directions of the $\mathrm{P}$ and $\mathrm{T}$ axes are determined by the equal area projection of the seismic moment tensors. We conclude that the orientations of the P-axes in Iran are dominantly NE, which affect the most target areas and nearly consistent with the orientations of the geodetic shortening.

The average seismic strain rate tensors and velocity tensors are determined for each study area. The $\lambda_{1}$ of the average seismic strain rates indicates that the compression component of the deformation exists in all of the regions. The results of the dilatation rate show that the Alborz and Makran orogenic belts have a subsidiary extensional component in some regions.

Based on the sign convention of $V_{33}$, we find that the vertical thinning of the seismogenic layer have occurred in the Alborz and eastern Iran and vertical thickening have occurred in the other regions. The values of $V_{33}$ indicate that left-lateral strike-slip motion affect the Alborz and eastern Iran, while right-lateral strikeslip motion affect the Kopeh-Dagh, Makran and Zagros orogenic belts.

The rates and orientations of the seismic deformation are calculated using the eigenvalues and eigenvectors of the velocity tensors. The eastern Iran, Alborz and SE Zagros have the highest seismic shortening rates, whereas the NW Zagros and Kopeh-Dagh, central Zagros and Makran have the lowest ones. The seismic shortening rate in the Zagros orogenic belt increases from NW to SE. The orientations of the seismic deformation are different from the P-axes, probably due to the lateral translation.

The percentage of the seismic deformation is de-

\begin{tabular}{cccccccc}
\hline & \multicolumn{8}{c}{ Zones } \\
\cline { 2 - 8 } & 1 & 2 & 3 & 4 & $5 \mathrm{a}$ & $5 \mathrm{~b}$ & $5 \mathrm{c}$ \\
\hline $\mathrm{A}\left(1 \times 10^{19}\right)$ & 1.09 & 9.19 & $4.47 \mathrm{e}-6$ & 0.122 & 61.9 & 11.6 & 819 \\
$\mathrm{~B}$ & 0.73 & 0.77 & 0.49 & 0.69 & 0.8 & 0.79 & 0.85 \\
$\dot{M}_{0}\left(1 \times 10^{26}\right)$ & 8.53 & 3.48 & 59.4 & 5 & 3.44 & 1.53 & 4.56 \\
\hline
\end{tabular}

Table 6. Seismic moment rates $\left(\dot{M}_{0}\right)$, parameters A and B from the Equations (8) and (9).

termined by dividing the seismic deformation rate on the geodetic deformation rate. Our work has led us to conclude that the eastern Iran has the most seismic deformation percentage among the study areas, while the Makran and Kopeh-Dagh have the lowest one.

Based on the eigensystems of the average shape tensor, it is concluded that the Kopeh-Dagh has the most fault plane solution similarity relative to the other orogenic belts.

The seismic moment rate is determined using the moment tensor components, frequency-magnitude and moment-magnitude relations in the study areas. We find that the eastern Iran has the largest size of deformation, while the central Zagros has the lowest one.

Acknowledgements. We thank Kh. Sarkarinejad, A. Khademi and M. Karami for reading the manuscript and helped in the mathematics. Special thanks to B. Oveisi for his helpful advices and comments. This work was supported by the Center of Excellence for Environmental Geohazards, and the Research Council of Shiraz University

\section{Data and resources}

The Global Centroid Moment Tensor Project database was searched using www.globalcmt.org/CMT search.html (last accessed on November 2013).

\section{References}

Aki, K., and P. Richards (1980). Quantitative Seismology: Theory and Methods, Freeman Co., San Francisco, $557 \mathrm{pp}$.

Allen, M.B., M.R. Ghassemi, M. Shahrabi and M. Qorashi (2003). Accommodation of late Cenozoic oblique shortening in the Alborz range, northern Iran, J. Struct. Geol., 25 659-672.

Allen, M.B., J. Jackson and R. Walker (2004). Late Cenozoic reorganization of the Arabia-Eurasia collision and the comparison of short-term and long-term deformation rates, Tectonics, 23, 1-16.

Allen, M.B., E.J. Blanc, R. Walker, J. Jackson, M. Talebian and M.R. Ghassemi (2006). Contrasting styles of convergence in the Arabia-Eurasia collision: Why escape tectonics does not occur in Iran, GSA Special Papers, 409, 579-589.

Barzi, M.H., and C.J. Talbot (2003). A tectonic pulse in 
the Makran accretionary prism recorded in Iranian coastal sediments, J. Geol. Soc. London, 160, 903-910.

Bayer, R., J. Chéry, M. Tatar, P. Vernant, M. Abbassi, F. Masson, F. Nilforoushan, E. Doerflinger, V. Regard and O. Bellier (2006). Active deformation in ZagrosMakran transition zone inferred from GPS measurements, Geophys. J. Int., 165, 373-381.

Berberian, M. (1981). Active faulting and tectonics of Iran, In: H.K. Gupta and F.M. Delany (eds.), Zagros, Hindu Kush, Himalaya: Geodynamic Evolution, Am. Geophys. Union Geodynamics series, 3, 33-69.

Berberian, M. (1995). Master "blind" thrust faults hidden under the Zagros folds: active basement tectonics and surface morphotectonics, Tectonophysics, 241, 193-224.

Blanc, E.J.-P., M.B. Allen, S. Inger and H. Hassani (2003). Structural styles in the Zagros Simple Folded Zone, Iran J. Geol. Soc., 160, 401-412; doi:10.1144/ 0016764902-110.

Bressan, G., P. Bragato and C. Venturini (2003). Stress and strain tensors based on focal mechanisms in the seismotectonic framework of the Friuli-Venezia Guilia region (northeastern Italy), B. Seismol. Soc. Am., 93, 1280-1297.

Bus, Z., Gy. Grenerczy, T. Tóth and P. Mónus (2009). Active crustal deformation in two seismogenic zones of the Pannonian region - GPS versus seismological observations, Tectonophysics, 474, 343-352.

Byrne, D.E., L.R. Sykes and D.M. Davis (1992). Great Thrust earthquakes and aseismic slip along the Plate Boundary of the Makran Subduction Zone, J. Geophys. Res., 97, 449-478.

DeMets, C., R.G. Gordon, D.F. Argus and S. Stein (1990). Current plate motions, Geophys. J. Int., 126, 805-818.

DeMets, C., R.G. Gordon, D.F. Argus and S. Stein (1994). Effects of recent revisions to the geomagnetic time scale on estimates of current plate motions, Geophys. Res. Lett., 21, 2191-2194.

Ekstrom, G., and P. England (1989). Seismic strain rates in regions of distributed continental deformation, J. Geophys. Res., 94, 10231-10257.

Engdahl, E.R., J.A. Jackson, S.C. Myers, E.A. Bergman and K. Priestley (2006). Relocation and assessment of seismicity in the Iran region, Geophys. J. Int., 167, 761-778.

Falcon, N.L. (1969). Problems of the relationship between surface structure and deep displacements illustrated by the Zagros range, In: P.E. Kent, G.E. Satterthwaite and A.M. Spencer (eds.), Time and Place in Orogeny, Geol. Soc. London Special Publications, 3, 9-22.

Falcon, N.L. (1974). Southern Iran: Zagros Mountains, In: A.M. Spencer (ed.), Mesozoic-Cenozoic Oro- genic Belts: Data for Orogenic Studies, Geol. Soc. London Special Publications, 4, 199-211.

Frohlich, C., and D. Apperson (1992). Earthquake focal mechanisms, moment tensors, and the consistency of seismic activity near plate boundaries, Tectonics, 11, 279-296.

Grando, G., and K. McClay (2007). Morphotectonics domains and structural styles in the Makran accretionary prism, offshore Iran, Sediment. Geol., 196, 157-179.

Guzmán-Speziale, M., and J.M. Gómez-González (2006). Seismic Strain rate along the Middle America Trench reveals significant differences between Cocos-North America and Cocos-Caribbean convergence, Geophys. J. Int., 166, 179-185.

Hatzfeld, D., C. Authemayou, P. Van Der Beek, O. Beller, B. Lave, B. Oveisi, M. Tatar, F. Tavakoli, A. Walpersdorf and F. Yamini-Fard (2010). The kinematics of the Zagros Mountains (Iran), Geol. Soc. London Special Publications, 330, 19-42.

Hessami, Kh., F. Nilforoushan and Ch. Talbot (2006). Active deformation within the Zagros Mountains deduced from GPS measurements, J. Geol. Soc. London, 163, 143-148.

Hollingsworth, J., J. Jackson, R. Walker, M.R. Gheitanchi and M.J. Bolourchi (2006). Strike-slip faulting, rotation, and along-strike elongation in the Kopeh Dagh mountains, NE Iran, Geophys. J. Int., 166, 1161-1177.

Jackson, J., and D. McKenzie (1984). Active tectonics of the Alpine-Himalayan Belt between western Turkey and Pakistan, Geophys. J. Roy. Astr. S., 77, 185-264.

Jackson, J., and D. McKenzie (1988). The relationship between plate motions and seismic moment tensors, and the rates of active deformation in the Mediterranean and Middle East, Geophys. J. Int., 93, 45-73.

Jackson, J., J. Haines and W. Holt (1995). The accommodation of Arabia-Eurasia plate convergence in Iran, J. Geophys. Res., 100, 15205-15219.

Jackson, J., K. Priestley, M.B. Allen and M. Berberian (2002). Active tectonics of the South Caspian Basin, Geophys. J. Int., 148, 214-245.

Jafari, M.A. (2007). Time independent seismic hazard analysis in Alborz and surrounding area, Nat. Hazards, 42, 237-252.

Kanamori, H., and D. Anderson (1975). Theoretical basis of some empirical relations in seismology, B. Seismol. Soc. Am., 65, 1073-1095.

Khazaradze, G., and J. Klotz (2003). Short- and longterm effects of GPS measured crustal deformation rates along the south central Andes, J. Geophys. Res. - Sol. Ea., 108, 2289; doi:10.1029/2002JB001879.

Kiratzi, A.A. (1991). Rates of crustal deformation in the 
North Aegean trough-North Anatolian fault deduced from seismicity, Pure Appl. Geophys., 136, 421-432.

Kiratzi, A.A. (1993). Active deformation in the Vrancea region, Rumania, Pure Appl. Geophys., 140, 391-402.

Kiratzi, A.A. (1994). Active seismic deformation in the Italian peninsula and Sicily, Annali di Geofisica, 37 (1), 27-45.

Kiratzi, A.A., and C.B. Papazachos (1995). Active crustal deformation from the Azores triple junction to the Middle East, Tectonophysics, 243, 1-24.

Klotz, J., A. Abolghasem, G. Khazaradze, B. Heinze, T. Vietor, R. Hackney, K. Bataille, R. Maturana, J. Viramonte and R. Perdomo (2006). Long-term signals in the present-day deformation field of the Central and Southern Andes and constraints on the viscosity of the Earth's upper mantle, In: O. Oncken et al. (eds.), The Andes active subduction orogeny, Frontiers in Earth Science Series, Springer-Verlag, Berlin/Heidelberg/New York, 1, 65-90.

Kostrov, B.V. (1974). Seismic moment and energy of earthquakes, and seismic flow of rock, Izv., Earth Physics, Russian Academy of Sciences, 1, 23-40.

Kostrov, B.V., and S. Das (1988). Principles of Earthquake Source Mechanics, Cambridge University Press, 308 pp.

Masson, F., J. Chrey, D. Hatzfeld, J. Martinod, P. Vernant, F. Tavakoli and M. Ghafory-Ashtiani (2005). Seismic versus aseismic deformation in Iran inferred from earthquakes and geodetic data, Geophys. J. Int., 160, 217-226.

Masson, F., M. Anvari, Y. Djamour, A. Walpersdorf, F. Tavakoli, M. Daignieres, H. Nankali and S. Van Gorp (2007). Large-scale velocity field and strain tensor in Iran inferred from GPS measurements: new insight for the present-day deformation pattern within NE Iran, Geophys. J. Int., 170, 436-440.

McCall, G.J.H. (1997). The geotectonic history of the Makran and adjacent areas of southern Iran, J. Asian. Sci., 15, 517-531.

McClusky, S., S. Balassanian, A. Barka, C. Demir, S. Ergintav, I. Georgiev, O. Gurkan, M. Hamburger, K. Hurst, H. Kahle, K. Kastens, G. Kekelidze, R. King, V. Kotzetv, O. Lenk, S. Mahmoud, A. mishin, M. Nadariya, A. Ouzounis, D. Paradissis, Y. Peter, M. Prilepin, R. Reilinger, I. Sanli, H. Seeger, A. Tealeb, M.N. Toksöz and G. Veis (2000). Global Positioning System constraints on plate kinematics and dynamics in the eastern Mediterranean and Caucasus, J. Geophys. Res., 105, 5695-5719.

Molnar, P. (1979). Earthquake recurrence intervals and plate tectonics, B. Seismol. Soc. Am., 69, 115-133.

Mouthereau, F., C. Fillon and K.F. Ma (2009). Distribu- tion of strain rates in the Taiwan orogenic wedge, Earth Planet. Sci. Lett., 284, 361-385.

Nilforoushan, F., F. Masson, P. Vernant, C. Vigny, J. Martinod, M. Abbassi, H. Nankali, D. Hatzfeld, R. Bayer, F. Tavakoli, A. Ashtiani, E. Doerflinger, M. Daignières, P. Collard and J. Chéry (2003). GPS network monitors the Arabia-Eurasia collision deformation in Iran, J. Geodesy, 77, 411-422.

Papazachos, C.B., and A.A. Kiratzi (1992). A formulation for reliable estimation of active crustal deformation and its application to central Greece, Geophys. J. Int., 111, 424-432.

Papazachos, C.B., and A.A. Kiratzi (1996). A detailed study of the active crustal deformation in the Aegean and surrounding area, Tectonophysics, 253, 129-153.

Peyret, M., Y. Djamour, K. Hessami, V. Regard, O. Bellier, Ph. Vernant, M. Daignières, H. Nankali, S. Van Gorp, M. Goudarzi, J. Chéry, R. Bayer and M. Rigoulay (2009). Present-day strain distribution across the Minab-Zendan-Palami fault system from dense GPS transects, Geophys. J. Int., 179, 751-762; doi:10.1111/j.1365-246X.2009.04321.x.

Pondrelli, S., A. Morelli and E. Boschi (1995). Seismic deformation in the Mediterranean area estimated by moment tensor summation, Geophys. J. Int., 122, 938-952.

Qin, C.H., C. Papazachos and E. Papadimitriou (2002). Velocity field for crustal deformation in China derived from seismic moment tensor summation of earthquakes, Tectonophysics, 35, 29-46.

Regard, V., D. Hatzfeld, M. Molinaro, C. Aubourg, R. Bayer, O. Bellier, F. Yamini- Fard, M. Peyret and M. Abbassi (2010). The transition between Makran subduction and the Zagros collision: recent advances in its structure and active deformation, Geol. Soc. London Special Publications, 330, 43-64.

Ritz, J.-F., H. Nazari, A. Ghassemi, R. Salamati, A. Shafei, A. Solaymani and P. Vernant (2006). Active transtension inside central Alborz: A new insight into northern Iran-southern Caspian geodynamics, Geology, 34, 477-480.

Singh, D. (2000). Seismotectonics of the Himalaya and its vicinity from centroid- moment tensor (CMT) solution of earthquakes, J. Geodyn., 30, 507-537.

Smith, G., L. McNeill, T.J. Henstock and J. Bull (2012). The structure and fault activity of the Makran accretionary prism, J. Geophys. Res., 117, B07407; doi:10.1029/2012JB009312.

Sobouti, F., and J. Arkani-Hamed (1996). Numerical modeling of the deformation of the Iranian Plateau, Geophys. J. Int., 126, 805-818.

Stein, S., and M. Wysession (2003). An introduction to seismology, earthquakes, and Earth structure, Black- 
well Publishing, 498 pp.

Stephen, J., and S. Singh (2004). Correlation of Effective Elastic Thickness and Seismogenic Thickness in the Continental Lithosphere of India, Am. Geophys. Union, Spring Meeting, abstract \#T21B-01.

Talebian, M., and J. Jackson (2004). A reappraisal of earthquake focal mechanisms and active shortening in the Zagros mountains of Iran, Geophys. J. Int., 156, 506-526.

Tatar, M., D. Hatzfeld, J. Martinod, A. Walpersdorf, M. Ghafori-Ashtiani and J. Chéry (2002). The presentday deformation of the central Zagros from GPS measurements, Geophys. Res. Lett., 29, 1927; doi:10. $1029 / 2002$ GL015427.

Tchalenko, J.S. (1975). Strain and deformation rates at the Arabia/Iran plate boundary, J. Geol. Soc. London, 131 ('State of the art' seminar 1975 on rates of deformation), 585-586.

Tselentis, G., and C. Makropoulos (1986). Rates of crustal deformation in the Gulf of Corinth (central Greece) as determined from seismicity, Tectonophysics, 124, 55-66.

Vamvakaris, D.A., C.B. Papazachos, E.E. Karagianni, E.M. Scordilis and P.M. Hatzidimitriou (2006). Small-scale spatial variation of the stress field in the back-arc Aegean area: Results from the seismotectonic study of the broader area of Mygdonia basin (N. Greece), Tectonophysics, 417, 249-267.

Vernant, P., F. Nilforoushan, D. Hatzfeld, M. Abbassi, C. Vigny, F. Masson, H. Nankali, J. Martinod, A. Ashtiani, R. Bayer, F. Tavakoli and J. Chéry (2004). Present-day crustal deformation and plate kinematics in the Middle East constrained by GPS measurements in Iran and northern Oman, Geophys. J. Int., 157, 381-398.

Vernant, P., and J. Chéry (2006). Low fault friction in Iran implies localized deformation for the ArabiaEurasia collision zone, Earth Planet. Sci. Lett., 246, 197-206.

Walker, R.T., and M. Khatib (2006). Active faulting in the Birjand region of NE Iran, Tectonics, 25, TC4016; doi:10.1029/2005TC001871.

Ward, S.N. (1998a). On the consistency of earthquake moment rates, geological fault data, and space geodetic strain: the United States, Geophys. J. Int., 134, 172-186.

Ward, S.N. (1998b). On the consistency of earthquake moment release and space geodetic strain rates: Europe, Geophys. J. Int., 135, 1011-1018.

Wesnousky, S.G., L.M. Jones, C.H. Scholz and Q. Deng (1984). Historical seismicity and rates of crustal deformatiom along the margins of the Ordo Block, North China, B. Seismol. Soc. Am., 74, 1767-1783.
Wiemer, S., and M. Wyss (2000). Minimum Magnitude of Completeness in Earthquake Catalogs: Examples from Alaska, the Western United States, and Japan, B. Seismol. Soc. Am., 90, 859-869.

Wiemer, S. (2001). A software package to analyze seismicity: ZMAP, Seismol. Res. Lett., 72, 373-382.

Yang, Y., and M. Liu (2010). What drives short- and long-term crustal deformation in the southwestern United States?, Geophys. Res. Lett., 37, L04306; doi:10.1029/2009GL041598.

Zamani, A., and N. Hashemi (2000). A comparison between seismicity, topographic relief, and gravity anomalies of the Iranian Plateau, Tectonophysics, 327, 25-36.

Zamani, B., J. Angelier and A. Zamani (2008). State of stress induced by plate convergence and stress partitioning in northeastern Iran, as indicated by focal mechanisms of earthquakes, J. Geodyn., 45, 120-132.

Zarifi, Z., F. Nilfouroushan and M. Raeesi (2013). Crustal stress map of Iran: insight from seismic and geodetic computations, Pure Appl. Geophys.; doi:10.1007/s00 024-013-0711-9.

\footnotetext{
${ }^{\star}$ Corresponding author: Shoja Ansari,

Shiraz University, Department of Earth Sciences, Shiraz, Iran; email: shojaansari@yahoo.com.

C 2014 by the Istituto Nazionale di Geofisica e Vulcanologia. All rights reserved.
} 